\title{
KONSEP AIR VIRTUAL (VIRTUAL WATER CONCEPT)
}

\author{
Budi Harsoyo ${ }^{1}$
}

\begin{abstract}
The emergence of virtual water concept originated from the awareness about the depletion of water supplies from the world today that require us to begin to think of ways to save the water. The concept which has revealed the reality of paradoxical transfer of water from water surplus areas to water crisis areas in virtual has been applied by some countries that began experiencing water scarcity is currently in its international trade activities. This paper aims to review the concept of virtual water, based on a review of several papers and articles dealing with related themes. This paper also explained about the definition of virtual water, how is it calculated, and the significance of this concept in relation to international water trading and water conservation movement globally.
\end{abstract}

\section{Intisari}

\begin{abstract}
Munculnya konsep air virtual berasal dari kesadaran tentang menipisnya persediaan air dari dunia saat ini yang mengharuskan kita untuk mulai memikirkan cara-cara untuk menghemat air. Konsep yang telah mengungkapkan realitas paradoks transfer air dari daerah surplus ke daerah air krisis air secara virtual telah diterapkan oleh beberapa negara yang mulai mengalami kelangkaan air saat ini dalam kegiatan perdagangan internasional. Makalah ini bertujuan untuk meninjau konsep air virtual, berdasarkan review beberapa makalah dan artikel yang berhubungan dengan tema terkait. Makalah ini juga menjelaskan tentang definisi air virtual, bagaimana cara menghitungnya, dan signifikansi konsep ini dalam kaitannya dengan perdagangan internasional dan pergerakan air konservasi air secara global.
\end{abstract}

Keywords : virtual water, water scarcity, water conservation

\section{PENDAHULUAN}

Pernahkan kita menyadari bahwa jika kita minum secangkir kopi berarti sesungguhnya kita juga meminum air sebanyak 140 liter? Atau jika kita membeli $1 \mathrm{~kg}$ daging sapi, secara tidak langsung kita juga telah membeli sebanyak 16.000 liter air yang terkandung di dalamnya. Pada umumnya kita tidak pernah menyadari bahwa dalam kehidupan sehari-hari telah menggunakan air dalam jumlah yang cukup banyak, yang mungkin saja kita serap dari berbagai penjuru dunia. Kandungan air sebanyak 140 liter untuk secangkir kopi atau 16.000 liter dalam $1 \mathrm{~kg}$ daging sapi dalam contoh di atas inilah yang disebut sebagai air virtual (virtual water), sebuah konsep yang memperhitungkan jumlah air yang dibutuhkan untuk memproduksi suatu komoditi pertanian ataupun industri.

\footnotetext{
${ }^{1}$ Peneliti Pertama UPT Hujan Buatan BPP Teknologi, Jalan MH. Thamrin no. 8, Gd.I Lt.19, Jakarta Pusat

E-mail : buhar04@yahoo.com
}

Krisis air dunia saat ini sudah masuk pada tahap genting. Menurut Balitbang Pertanian (2003) satu dari empat orang di dunia kekurangan air minum dan satu dari tiga orang tidak mendapat sarana sanitasi yang layak. Menjelang tahun 2025, sekitar 2,7 milyar orang atau sekitar sepertiga populasi dunia akan menghadapi kekurangan air dalam tingkat yang parah. Karena itu, harus ada upaya segera untuk menemukan solusi menghadapi hal ini.

Mulai semakin menipisnya cadangan air dunia saat ini mengharuskan kita untuk mulai memikirkan cara bagaimana usaha menghemat air. Munculnya konsep air virtual berawal dari pemikiran seperti itu. Konsep air virtual pertama kali dicetuskan oleh Tony Allan dari University of London pada awal tahun 90'an. Beberapa negara yang mengalami kelangkaan air saat ini mulai menerapkan konsep air virtual dalam aktifitas perdagangan internasionalnya. Konsep yang telah mengungkap kenyataan adanya paradoksal transfer air dari daerah yang surplus air ke daerah 
krisis air secara virtual ini pertama kali didiskusikan dalam forum internasional pada bulan Desember 2002 di Delft, Belanda. Selanjutnya konsep ini didiskusikan secara khusus dan mulai menjadi isu yang mendunia dalam Third World Water Forum di Jepang, Maret 2003. Sebagai pencetus konsep air virtual, Tony Allan mendapatkan penghargaan nobel pada tahun 2008 atas pemikirannya tersebut.

Tulisan ini bertujuan untuk mengulas konsep air virtual, berdasarkan hasil review dari beberapa tulisan maupun artikel yang membahas tema terkait. Dalam tulisan ini dijelaskan mengenai definisi air virtual, bagaimana cara menghitungnya, maupun arti penting konsep ini dalam kaitannya dengan perdagangan air internasional dan gerakan konservasi air secara global.

\section{DEFINISI AIR VIRTUAL (VIRTUAL WATER)}

Istilah air virtual (virtual water) dapat didefinisikan sebagai jumlah air yang digunakan dalam proses produksi dari suatu suatu komoditi hasil produksi pertanian ataupun industri. Hoekstra (2003) mencoba membuat konsep air virtual menjadi sesuatu yang nyata, dengan tujuan utama untuk melacak dan memetakan berapa banyak air yang diperlukan untuk memproduksi sesuatu. Menurutnya nilai kandungan air virtual dapat berbeda meskipun untuk memproduksi komoditi yang sama dengan jumlah yang sama pula. Hal ini tergantung kepada situasi dan kondisi saat proses produksinya, termasuk waktu dan tempat dimana proses produksi tersebut berlangsung. Misalnya, kandungan air virtual dalam $1 \mathrm{~kg}$ padi, tentunya volume air yang dibutuhkan di daerah beriklim kering akan lebih banyak jumlahnya dibandingkan dengan di daerah beriklim tropis.

Perbedaan yang jelas dalam penggunaan air dapat terlihat di beberapa benua. Menurut Daniel Zimmer, Direktur Badan Air Dunia (2003), masyarakat di Asia menggunakan rata-rata 1.400 liter air virtual setiap hari. Sementara di Eropa dan Amerika Utara, penduduknya mengkonsumsi sekitar 4.000 liter air virtual setiap hari. Umumnya sebanyak $70 \%$ seluruh air itu tersalurkan untuk pertanian.

Dalam kaitannya dengan perdagangan antar negara, air virtual terkadang disebut juga dengan istilah embedded water atau exogenous water. Jika sebuah produk diimpor dari suatu negara ke negara lain, maka sesungguhnya negara tujuan tersebut telah menggunakan air secara virtual dari negara asal dimana produk tersebut diproduksi. Jadi air yang berada di suatu tempat sesungguhnya juga secara tidak langsung dipakai untuk memenuhi kebutuhan di tempat lain menurut konsep air virtual ini.

\section{DEFINISI AIR TAPAK (WATER FOOT- PRINT)}

Konsep air virtual memungkinkan untuk membuat analisa pengaruh pola konsumsi pada penggunaan air. Analisa tersebut menghasilkan apa yang dikenal dengan istilah air tapak (water footprint) suatu negara. Air tapak suatu negara adalah sama dengan penggunaan sumber air domestik, dikurangi aliran ekspor air virtual, ditambah aliran impor air virtual.

Air tapak (water footprint) didefinisikan sebagai total volume air tawar (fresh water) yang digunakan untuk menghasilkan barang atau jasa yang dikonsumsi oleh individu maupun kelompok masyarakat, atau juga oleh dunia usaha. Jadi air tapak merupakan indikator yang dapat menggambarkan jumlah air tawar (fresh water) yang digunakan dalam proses produksi suatu produk baik secara langsung maupun tidak langsung.

Mengimpor air virtual dengan demikian dapat dijadikan alternatif sumber air untuk mengurangi beban sumber air pada negara-negara pengimpor

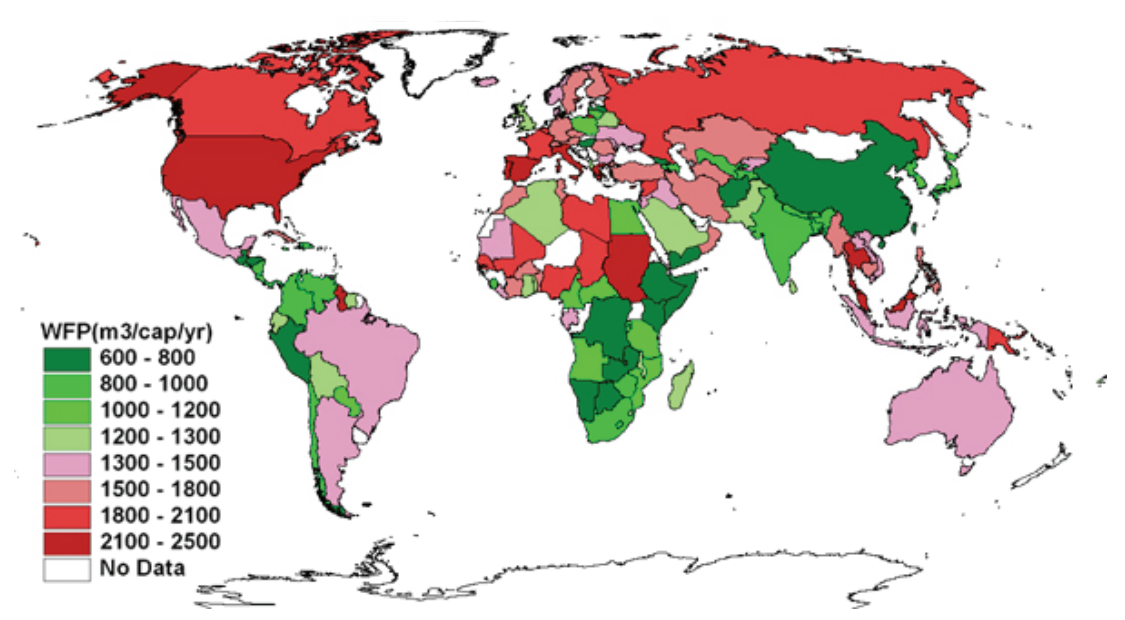

Gambar 1. Nilai rerata air tapak (water footprint) dari negara - negara di seluruh dunia (m3/kapita/tahun), dihitung untuk periode 1997 - 2001 (sumber : www.waterfootprint.org ) 
air virtual. Neraca air real dan neraca air virtual pada suatu negara sangat erat kaitannya. Sebagai ilustrasi, berikut ini dicontohkan neraca air negara Cina tahun 1999. Total penggunaan air domestik negara tersebut adalah 1.375 miliar $\mathrm{m}^{3}$ per tahun, di mana 1,2 \% digunakan untuk ekspor. Water footprint di Cina adalah 1.392 miliar $\mathrm{m}^{3}$ per tahun, yang dibebankan pada sumber domestik 97,6 \% dan sisanya 2,4\% dari sumber air luar negeri. Nilai air virtual tersebut tidak terlalu banyak, tetapi akan terus meningkat di masa yang akan datang.

Gambar 1 menunjukkan kalkulasi air tapak rerata dari negara - negara di seluruh dunia $\left(\mathrm{m}^{3} /\right.$ kapita/tahun), dihitung untuk periode 1997 - 2001. Warna hijau menunjukkan bahwa air tapak pada negara yang bersangkutan adalah sama dengan atau kurang dari rerata keseluruhan secara global.

\section{TRANSFER AIR VIRTUAL DALAM PERDAGANGAN INTERNASIONAL}

Dalam Hoekstra (2003) dijelaskan bahwa keadaan saat ini menunjukkan hampir $20 \%$ air yang digunakan oleh sektor pertanian diperdagangkan ke negara lain dalam bentuk pangan dan produk lain yang dihasilkannya. Ini merupakan jumlah yang sangat besar karena 5 triliun $\mathrm{m}^{3}$ air per tahun digunakan untuk pertanian dan di luar itu sebanyak 1 triliun $\mathrm{m}^{3}$ air diperdagangkan antar negara. Amerika Serikat merupakan negara pengekspor utama air virtual karena ekspor pertaniannya, sementara beberapa negara lainnya seperti Kanada, Thailand, Argentina, India, Vietnam, Perancis dan Brasil juga memiliki ekspor neto air virtual sehingga tidak bergantung pada sumber air luar negeri. Sedangkan beberapa negara pengimpor murni air virtual adalah Sri Lanka, Jepang, Belanda, Korea Selatan, Cina, Spanyol, Mesir, Jerman, dan Italia. Sebagai perbandingan, ekspor air virtual Amerika Serikat setiap tahunnya empat kali lipat dari seluruh air yang secara nyata digunakan untuk berbagai hal di Mesir.
Hoekstra (2003) menduga jumlah total penggunaan air dunia untuk keperluan domestik dan industri sebesar $1.200 \mathrm{Gm}^{3}$ per tahun. Total air yang digunakan manusia bukan untuk konsumsi domestik, namun untuk keperluan ekspor (dalam bentuk virtual) adalah sekitar $15 \%$. Dari gambaran tersebut dapat dikatakan bahwa $15 \%$ dari air dunia digunakan bukan untuk memenuhi kebutuhan domestik, tetapi untuk memenuhi kebutuhan luar negeri yang keberadaannya di belahan benua lain. Dengan kata lain dapat disimpulkan bahwa bila terjadi gangguan terhadap sistem air regional, maka $15 \%$ berkaitan dengan kebutuhan untuk menghasilkan produk yang menggunakan air di negara lain. Dengan makin pesatnya proses globalisasi terutama perdagangan global, telekoneksi air virtual ini akan menjadi semakin penting di masa mendatang.

Secara tidak sadar bahwa dengan mengimpor makanan, banyak negara yang kekurangan air telah mengurangi masalah air mereka sehingga impor air virtual telah memainkan peranannya dalam hal ini. Karenanya disarankan agar setiap negara yang terlibat dalam perdagangan air virtual mulai menerapkan konsep tersebut secara lebih sadar. Para pemerintah harus mulai berpikir bagaimana membagi keuntungan dari air, selain berbagi air.

Seperti diketahui, emisi lokal gas rumah kaca menyumbangkan perubahan pada iklim global sehingga mempengaruhi suhu, evaporasi, dan pola curah hujan di tempat lain. Disamping itu, ada mekanisme lain di mana suatu negara mempengaruhi sistem air negara lain.

Terdapat hubungan langsung antara suatu produk yang membutuhkan banyak air (terutama tanaman) di negara-negara seperti Indonesia dan Brasil, misalnya, serta air yang digunakan untuk memproduksi barang-barang ekspor di negara seperti Amerika dan Australia. Air yang digunakan untuk memproduksi barang ekspor secara nyata menyumbang perubahan sistem hidrologi skala regional dan lokal.

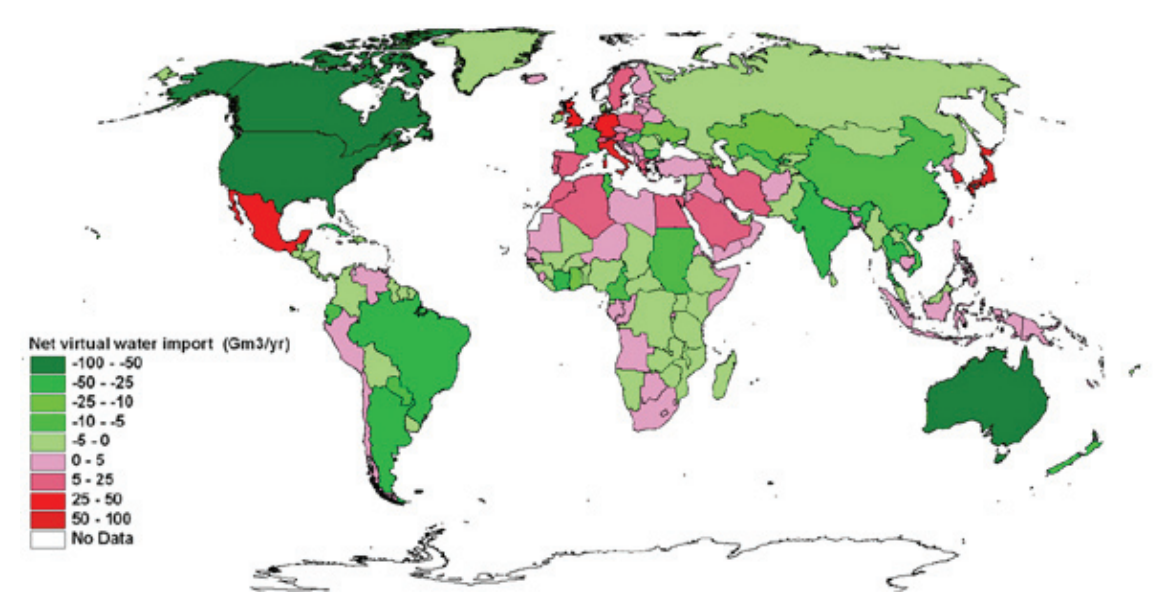

Gambar 2. Neraca air virtual negara-negara di seluruh dunia berdasarkan aktifitas perdagangan internasional, untuk periode 1997 - 2001 (sumber : www.waterfootprint.org) 


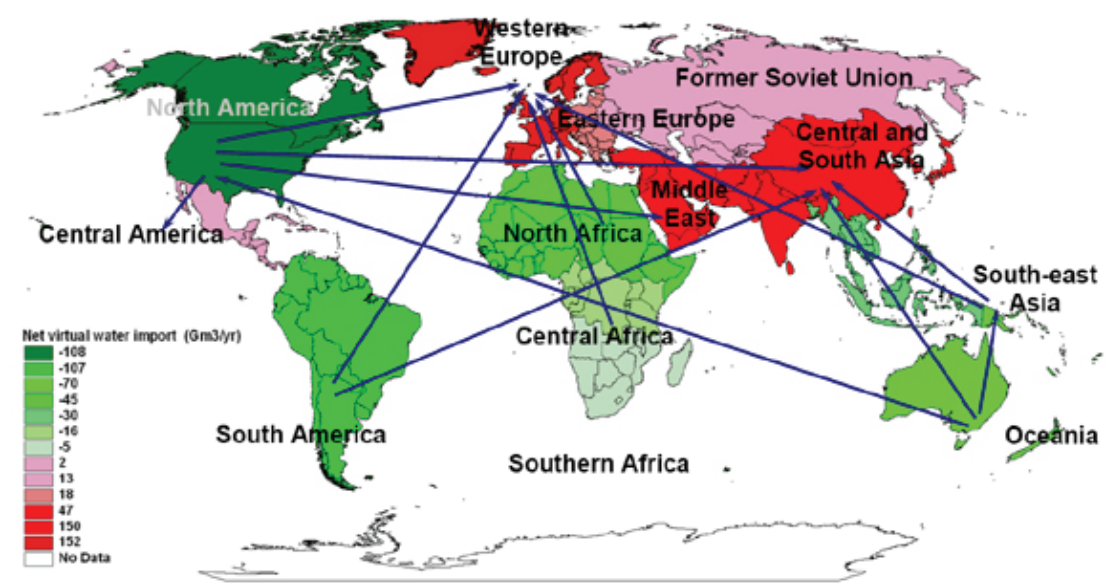

Gambar 3. Aliran transfer neraca air virtual negara-negara di seluruh dunia berdasarkan aktifitas perdagangan internasional, untuk periode 1997 - 2001 (sumber : www.waterfootprint.org )

Hoekstra (2003) menerangkan bahwa para konsumen di Jepang telah mempengaruhi sumber air di Amerika, menyumbang pada pengeboran sumur artesis di Ogallala, mengurangi debit Sungai Colorado, dan meningkatkan evaporasi di Amerika Utara. Para konsumen di Belanda pun secara nyata telah menyumbangkan tingkat kebutuhan air di Brasil.

Bagaimana menjelaskan telekoneksi sistem air global ini melalui mekanisme perdagangan global? Gambar 2 memperlihatkan neraca air virtual seluruh negara di dunia berdasarkan interaksinya dalam perdagangan internasional, sementara aliran transfer air virtualnya diperlihatkan pada Gambar 3. Negara-negara pengekspor air virtual ditunjukkan dengan warna hijau, sedangkan negara-negara pengimpor berwarna merah.

Dasar pendekatan untuk menduga aliran air virtual antarnegara adalah mengalikan volume perdagangan internasional (ton/tahun) dengan kandungan air virtualnya ( $\left.\mathrm{m}^{3} / \mathrm{ton}\right)$. Kandungan air virtual beberapa jenis tanaman telah diestimasi menggunakan berbagai basis data dari FAO (CropWat, ClimWat, FAOSTAT). Berbeda dengan tanaman, kandungan air virtual dari hewan ternak dihitung melalui jalur "pohon produksi" yang menunjukkan tingkat produksi yang berbeda. Kandungan air virtual daging bergantung pada kandungan air virtual kerangkanya yang akhirnya bergantung pada kandungan air dari binatang hidup. Secara umum kandungan air virtual hewan bergantung pada kandungan air virtual dari pakan yang dikonsumsi ditambah air untuk minumnya dan untuk membersihkan kandang.

\section{KONSEP AIR VIRTUAL DAN PEMBANGUNAN IRIGASI DI INDONESIA}

Badan Litbang Pertanian (2003) menyebutkan bahwa menurut Organisasi Pangan dan Pertanian
Dunia (FAO) sudah waktunya sektor pertanian yang selama ini menggunakan air paling banyak mulai melakukan penghematan air. Teknologi irigasi harus diperbarui dan investasi sarana pengairan harus ditingkatkan untuk mendukung produksi pangan yang hemat air sehingga krisis pangan di masa yang akan datang dapat dihindarkan.

Masalah air dan ketahanan pangan di beberapa wilayah perlu segera dibahas. Jika ingin terhindar dari krisis pangan di masa depan, maka dibutuhkan investasi dan teknologi baru dalam pengelolaan air. Satu dari lima negara berkembang akan mengalami kekurangan air pada tahun 2030. Padahal pada tahun itu kebutuhan air untuk pertanian akan meningkat $14 \%$ pada saat kebutuhan pangan meningkat $60 \%$.

Sutopo (2008) membuat suatu proyeksi untuk mendapatkan gambaran tingkat penggunaan potensi air untuk irigasi padi di seluruh Indonesia pada tahun 2005 secara makro dengan menggunakan konsep air virtual. Dengan membandingkan perkiraan produksi padi dan perkiraan kebutuhan padi, diperoleh angka neraca beras nasional per propinsi dan per pulau sehingga selanjutnya diketahui apakah defisit atau surplus. Hasil perhitungan disajikan pada Tabel 1.

Hanya 12 propinsi dari 30 propinsi yang mengalami surplus padi di tahun 2005. Surplus terbesar terdapat di daerah andalan irigasi: Propinsi Jawa Timur, Jawa Tengah dan Sulawesi Selatan, dengan surplus masing-masing lebih dari 1,5 juta ton padi. Keseluruhan produksi padi Pulau Jawa tahun 2005 hanya surplus 492.879 ton karena defisit yang terdapat di Propinsi DKI Jakarta, Banten dan Jawa Barat. Produksi padi Pulau Sumatera tidak dapat menutup kebutuhan konsumsi padinya. Defisit terbesar dialami oleh Propinsi Riau dengan lebih dari 1 juta ton padi. Dari sini dapat diperkirakan adanya distribusi beras dari daerah surplus ke daerah defisit. 
Tabel 1. Perkiraan Produksi vs Kebutuhan Padi Nasional, 2005

\begin{tabular}{|c|c|c|c|}
\hline Propinsi & $\begin{array}{l}\text { Produksi } \\
\text { Padi } \\
\text { (Ton) }\end{array}$ & $\begin{array}{c}\text { Perkiraan } \\
\text { Kebutuhan } \\
\text { Padi } \\
\text { (Ton) } \\
\end{array}$ & $\begin{array}{c}\text { Neraca Padi } \\
+/- \\
\text { (Ton) }\end{array}$ \\
\hline Nanggroe Aceh Darussalam & 1.159 .153 & 1.184 .800 & -25.647 \\
\hline Sumatera Utara & 3.361 .136 & 3.284 .400 & 76.736 \\
\hline Sumatera Barat & 1.879 .118 & 1.284 .000 & 595.118 \\
\hline Riau & 416.820 & 1.422 .700 & -1.005 .880 \\
\hline Jambi & 596.767 & 754.600 & -157.833 \\
\hline Sumatera Selatan & 1.937 .997 & 1.867 .600 & 70.397 \\
\hline Bengkulu & 417.743 & 534.800 & -117.057 \\
\hline Lampung & 2.118 .942 & 1.861 .100 & 257.842 \\
\hline Bangka Belitung & 12.166 & 237.100 & -224.934 \\
\hline Sumatera & 11.899 .842 & 12.431 .100 & -531.258 \\
\hline DKI Jakarta & 11.125 & 1.785 .900 & -1.774 .775 \\
\hline Banten & 1.825 .967 & 2.429 .600 & -603.633 \\
\hline Jawa Barat & 9.333 .618 & 10.225 .900 & -892.282 \\
\hline Jawa Tengah & 8.387 .571 & 6.658 .000 & 1.729 .571 \\
\hline DI Yogyakarta & 668.583 & 623.200 & 45.383 \\
\hline Jawa Timur & 9.000 .815 & 7.012 .300 & 1.988 .515 \\
\hline Ja wa & 29.227 .679 & 28.734 .800 & 492.879 \\
\hline Bali & 780.404 & 895.400 & -114.996 \\
\hline Nusa Tenggara Barat & 1.374 .996 & 1.222 .800 & 152.196 \\
\hline Nusa Tenggara Timur & 421.450 & 763.400 & -341.950 \\
\hline Kalimantan Barat & 1.127.256 & 1.096 .500 & 30.756 \\
\hline Kalimantan Tengah & 482.022 & 584.000 & -101.978 \\
\hline Kalimantan Selatan & 1.531 .102 & 778.700 & 752.402 \\
\hline Kalimantan Timur & 495.417 & 718.400 & -222.983 \\
\hline Kalimantan & 3.635 .797 & 3.177 .700 & 458.097 \\
\hline Sulawesi Utara & 420.529 & 523.900 & -103.371 \\
\hline Sulawesi Tengah & 759.539 & 607.700 & 151.839 \\
\hline Sulawesi Selatan & 3.854 .621 & 2.314 .000 & 1.540 .621 \\
\hline Sulawesi Tenggara & 317.129 & 416.600 & -99.471 \\
\hline Gorontalo & 164.582 & 210.900 & -46.318 \\
\hline Sulawesi & 5.516 .400 & 4.073 .100 & 1.443 .300 \\
\hline Maluku & 37.782 & 183.000 & -145.218 \\
\hline Maluku Utara & 57.851 & 123.800 & -65.949 \\
\hline Papua & 55.919 & 374.600 & -318.681 \\
\hline Indonesia & 53.008 .120 & 51.979 .700 & 1.028 .420 \\
\hline
\end{tabular}

(sumber : Sutopo, 2008)

Selain itu dihitung pula perbandingan besarnya potensi air yang harus dialokasikan untuk operasional jaringan irigasi saja. Besarnya kandungan air virtual produksi padi dan perkiraan potensi air masing-masing propinsi disusun dalam Tabel 2.

Dari Tabel 2 terlihat bahwa penggunaan air untuk irigasi di Pulau Jawa telah mencapai 51,21 $\%$ dari perkiraan total potensi air. Daerah Istimewa Yogyakarta merupakan daerah yang terbanyak menggunakan potensi airnya untuk irigasi yaitu $74,33 \%$, Ialu Propinsi Jawa Timur menggunakan $67,19 \%$, kemudian Jawa Barat (termasuk Banten) $52,89 \%$ dan Jawa Tengah sebanyak 41,75 \%. Propinsi Bali dan Nusa Tenggara Barat merupakan daerah di luar Pulau Jawa yang menggunakan potensi air terbesar, masing-masing telah mencapai
$44,48 \%$ dan 30,85 \%. Daerah lain masih di bawah angka $15 \%$ kecuali Propinsi Sulawesi Selatan yang telah mencapai angka $15,43 \%$.

Dengan surplus padi sebanyak 3.763 .469 ton (Tabel 1), Propinsi Jawa Tengah, DI Yogyakarta dan Jawa Timur sebenarnya mengekspor air virtualnya sebanyak 8.091.458.350 $\mathrm{m}^{3}$ ke daerah defisit padi, yakni 7.031.768.500 m3 ke daerah di Jawa Barat, Banten dan DKI Jakarta serta 1.059.689.850 m3 ke daerah lain diluar Pulau Jawa.

Studi FIDEP (1993, dalam Sutopo, 2008) telah menghitung proyeksi kebutuhan air (water demand) bulanan masing-masing untuk DMI (rumah tangga, perkotaan dan industri), pemeliharaan sungai, kolam perikanan, peternakan dan irigasi di tiap wilayah sungai pada tahun 2005, 2010, 2015 dan 2020. Proyeksi kebutuhan DMI telah 
Tabel 2. Air Virtual vs Potensi Air, 2005

\begin{tabular}{|c|c|c|c|c|}
\hline Propinsi & $\begin{array}{c}\text { Produksi } \\
\text { Padi } \\
\text { (Ton) } \\
\end{array}$ & $\begin{array}{c}\text { Kandungan Air } \\
\text { Virtual } \\
\left(\mathrm{m}^{3}\right)\end{array}$ & $\begin{array}{l}\text { Potensi Air } \\
\left.\left(\mathrm{m}^{3}\right)^{*}\right)\end{array}$ & $\begin{array}{c}\text { Air Virtual / } \\
\text { Potensi Air } \\
(\%)\end{array}$ \\
\hline Nanggroe Aceh Darussalam & 1.159 .153 & 2.492.178.950 & 43.439 .000 .000 & 5,74 \\
\hline Sumatera Utara & 3.361 .136 & 7.226 .442 .400 & 77.993 .000 .000 & 9,27 \\
\hline Sumatera Barat & 1.879 .118 & 4.040.103.700 & 33.076 .000 .000 & 12,21 \\
\hline Riau & 416.820 & 896.163 .000 & 114.650 .000 .000 & 0,78 \\
\hline Jambi & 596.767 & 1.283.049.050 & 46.827.000.000 & 2,74 \\
\hline Sumatera Selatan & 1.937 .997 & 4.166 .693 .550 & 106.486 .000 .000 & 3,94 \\
\hline Bengkulu & 417.743 & 898.147 .450 & 27.300 .000 .000 & 3,29 \\
\hline Lampung & 2.118 .942 & 4.555.725.300 & 32.432 .000 .000 & 14,05 \\
\hline Bangka Belitung & 12.166 & 26.156 .900 & -- & -- \\
\hline Sumatera & 11.899 .842 & 25.558 .503 .400 & 482.203 .000 .000 & 5,30 \\
\hline DKI Jakarta & 11.125 & 23.918 .750 & 3.406 .000 .000 & 0,70 \\
\hline Banten & 1.825 .967 & 3.925 .829 .050 & -- & -- \\
\hline Jawa Barat & 9.333 .618 & 20.067 .278 .700 & 45.368 .000 .000 & 52,89 \\
\hline Jawa Tengah & 8.387.571 & 18.033 .277 .650 & 43.194 .000 .000 & 41,75 \\
\hline DI Yogyakarta & 668.583 & 1.437 .453 .450 & 1.934 .000 .000 & 74,33 \\
\hline Jawa Timur & 9.000 .815 & 19.351 .752 .250 & 28.803 .000 .000 & 67,19 \\
\hline $\mathrm{J}$ a wa & 29.227 .679 & 62.839 .509 .850 & 122.705 .000 .000 & 51,21 \\
\hline Bali & 780.404 & 1.677 .868 .600 & 3.755 .000 .000 & 44,68 \\
\hline Nusa Tenggara Barat & 1.374 .996 & 2.956 .241 .400 & 9.584 .000 .000 & 30,85 \\
\hline Nusa Tenggara Timur & 421.450 & 906.117 .500 & 23.385 .000 .000 & 3,87 \\
\hline Kalimantan Barat & 1.127 .256 & 2.423 .600 .400 & 174.007 .000 .000 & 1,39 \\
\hline Kalimantan Tengah & 482.022 & 1.036.347.300 & 151.553 .000 .000 & 0,68 \\
\hline Kalimantan Selatan & 1.531 .102 & 3.291 .869 .300 & 47.173 .000 .000 & 6,98 \\
\hline Kalimantan Timur & 495.417 & 1.065 .146 .550 & 183.978 .000 .000 & 0,58 \\
\hline Kalimantan & 3.635 .797 & 7.816 .963 .550 & 556.711 .000 .000 & 1,40 \\
\hline Sulawesi Utara & 420.529 & 904.137 .350 & 17.541 .000 .000 & 7,17 \\
\hline Sulawesi Tengah & 759.539 & 1.633 .008 .850 & 46.669 .000 .000 & 3,50 \\
\hline Sulawesi Selatan & 3.854 .621 & 8.287 .435 .150 & 53.716 .000 .000 & 15,43 \\
\hline Sulawesi Tenggara & 317.129 & 681.827 .350 & 20.402 .000 .000 & 3,34 \\
\hline Gorontalo & 164.582 & 353.851 .300 & & \\
\hline Sulawesi & 5.516 .400 & 11.860 .260 .000 & 138.328 .000 .000 & 8,57 \\
\hline Maluku & 37.782 & 81.231 .300 & 37.681 .000 .000 & 0,55 \\
\hline Maluku Utara & 57.851 & 124.379 .650 & -- & -- \\
\hline $\mathrm{Papua}$ & 55.919 & 120.225 .850 & 359.398 .000 .000 & 0,03 \\
\hline Indonesia & 53.008 .120 & 113.967 .458 .000 & 1.733 .750 .000 .000 & 6,57 \\
\hline
\end{tabular}

Sumber: FIDEP (JICA, 1993) dalam Sutopo (2008)

disesuaikan dengan angka proyeksi penduduk yang digunakan dalam makalah ini dan kebutuhan pemeliharaan sungai disesuaikan dengan proyeksi penduduk perkotaan. Hasil perhitungan ini, kecuali kebutuhan air untuk irigasi menggunakan angka kandungan air virtual (Tabel 2), digunakan untuk mendapatkan perkiraan proyeksi neraca air di Pulau Jawa. Proyeksi tahun 2025 dalam makalah ini dianggap relatif sama dengan proyeksi tahun 2020 dan dengan mengasumsikan bahwa kinerja irigasi di Pulau Jawa telah mencapai titik optimum sehingga kebutuhan air untuk irigasi relatif konstan. Hasil perkiraan perbandingan antara potensi air dengan proyeksi kebutuhan air untuk Propinsi DI Yogyakarta dan Jawa Timur yang merupakan paling tinggi \%tasenya serta keseluruhan Pulau Jawa ditunjukkan pada Tabel 3.

Terlihat bahwa potensi air di Propinsi DI Yogyakarta telah terpakai seluruhnya untuk memenuhi kebutuhan irigasi, DMI, pemeliharaan sungai, kolam perikanan dan peternakan pada tahun 2005. Penggunaan air di Propinsi Jawa Timur telah mencapai $81 \%$ dari potensinya. Secara keseluruhan Pulau Jawa terindikasi telah harus menggunakan $65 \%$ dari total potensi airnya di tahun 2005. Beban Pulau Jawa dalam menyediakan padi nasional semakin berat salah satunya dengan semakin meningkatnya kebutuhan akan air tawar karena pertumbuhan penduduk, perkembangan perkotaan dan perindustrian. Proyeksi kebutuhan air baku untuk keperluan di luar irigasi meningkat dari 17,22 milyar $\mathrm{m}^{3}$ di tahun 2005 menjadi 24,7 milyar $\mathrm{m}^{3}$ di tahun 2025.

Irigasi di Pulau Jawa tidak mungkin dikembangkan lagi. Irigasi akan dikembangkan ke Pulau Sumatera dan Sulawesi. Dari Tabel 1 dan 2 terlihat bahwa dari sudut pandang konsep air virtual Pulau Sulawesi menunjukkan kinerja 
Tabel 3: Proyeksi Kebutuhan Air vs Potensi Air (dalam milyar $\mathrm{m}^{3}$ )

\begin{tabular}{|l|r|r|r|r|r|}
\hline \multicolumn{1}{|c|}{ Propinsi } & 2005 & 2010 & 2015 & 2020 & 2025 \\
\hline DI Yogyakarta & & & & & \\
\hline Potensi Air & 1,93 & 1,93 & 1,93 & 1,93 & 1,93 \\
Kebutuhan & 1,98 & 2,04 & 2,10 & 2,09 & 2,13 \\
\hline Jawa Timur & & & & & \\
\hline Potensi Air & 28,80 & 28,80 & 28,80 & 28,80 & 28,80 \\
Kebutuhan & 23,36 & 23,99 & 24,55 & 24,56 & 24,88 \\
\hline Pulau Jawa & & & & & \\
\hline Potensi Air & 123 & 123 & 123 & 123 & 123 \\
Kebutuhan & 80 & 83 & 86 & 86,2 & 87,9 \\
\hline
\end{tabular}

(sumber : Sutopo, 2008)

yang baik. Dengan menggunakan 8,57 \% potensi airnya untuk irigasi telah dapat menyumbang kepada padi ke daerah lain sebanyak 1.443 .300 ton yang setara dengan $3.103 .095 .000 \mathrm{~m}^{3}$ air virtual. Pulau Sumatera masih harus bekerja keras untuk menutup defisitnya sendiri namun potensi air dan lahan masih tersedia cukup besar untuk dikembangkan. Pulau Kalimantan dengan dominan daerah rawanya juga menunjukan kinerja yang baik dengan menyumbangkan 458.097 ton padinya ke daerah defisit.

\section{PENUTUP}

Menyikapi krisis air secara global, kiranya sudah waktunya masyarakat dan pemerintah Indonesia melihat kembali secara serius mengenai efisiensi pemanfaatan sumberdaya air. Saat ini masyarakat masih beranggapan air tersedia secara mudah dan gratis. Aksi penanganan masalah krisis air tersebut harus diprioritaskan pada empat hal, yaitu membangun etika baru soal air, menetapkan pendanaan, meningkatkan pengelolaan air untuk keamanan dan perdamaian dunia, serta memprioritaskan perhatian pada negara-negara berkembang dalam kaitannya perdagangan internasional dengan konsep air virtual .

Bila tidak ada teknologi serta investasi baru, peningkatan kebutuhan air untuk pertanian tidak bisa dipenuhi, akibatnya peningkatan produksi pangan tidak bisa dilakukan. Sementara kompetisi kebutuhan air antara sektor pertanian dengan sektor lainnya akan makin bertambah. Saat ini sektor pertanian menggunakan air paling banyak yaitu $70 \%$, sektor industri $20 \%$, dan rumah tangga $10 \%$.

Kesimpulannya, tanaman pangan ratarata menyerap air jauh lebih banyak daripada kebutuhan manusia untuk hidup sehari-hari, seperti untuk minum maupun keperluan mandi dan sanitasi. Berdasarkan pada menipisnya cadangan air dunia, kini banyak orang beramai-ramai memikirkan bagaimana usaha menghemat air. Sebuah pemikiran mulia andaikata kaum miskin dan orang tak berpunya benar-benar terbukti telah diposisikan sebagai pihak yang harus memperoleh prioritas pertama.

Akibat berbagai kerusakan lingkungan yang semakin memburuk, Indonesia menjadi pengimpor air virtual yang dari tahun ke tahun semakin besar. Kondisi ini sangat bertolak belakang dibandingkan dengan sejumlah negara maju yang meskipun menjadi pengimpor air virtual, namun mereka melakukan perbaikan lingkungannya hingga air semakin cukup tersedia untuk berbagai pemanfaatan oleh rakyatnya.

Yang perlu diwaspadai oleh Indonesia selaku negara berkembang adalah bahwa lembaga-lembaga bantuan keuangan seperti IMF, World Bank, ADB dan sebagainya ini, lebih sering menempatkan diri sebagai fasilitator para mafia air terutama di negara-negara sedang berkembang. Utang digelontorkan terus ke PDAM-PDAM tanpa melalui pertimbangan potensi dan kemampuan membayar utangnya. Targetnya, bila utang itu kemudian default, maka masuklah para mafia air untuk mengakuisisi PDAM. 


\section{DAFTAR PUSTAKA}

A.Y. Hoekstra. 2003. Virtual Water : an Introduction. Proceedings of the International Expert Meeting on Virtual Water Trade. IHE Delft. Netherlands. (downloaded from www.waterfootprint. org).

Dodo Gunawan. 2003. Konsep Air Virtual dan Perdagangan Air Antar Negara. Kompas, 23 Oktober 2003.
Badan Penelitian dan Pengembangan Pertanian. 2003. Sektor Pertanian Harus Menghemat Air. Departemen Pertanian RI. (di-download dari www.litbang.deptan. go.id)

Sutopo Purwo Nugroho. 2008. Konsep Air Virtual dan Pembangunan Irigasi. 